Original Article

Received/Accepted

Dates

10.09.2021/20.10.2021

DOI

10.52096/jsrbs.6.1.7.13.30
Journal of Social Research and Behavioral Sciences

Sosyal Araştırmalar ve Davranış Bilimleri Dergisi

ISSN:2149-178X

Volume: 7 Issue: 13 Year: 2021

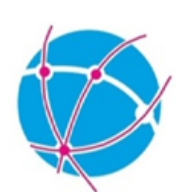

\title{
Eğitim Yöneticilerinin Stresle Başa Çıkma Stratejileri
}

Sakin Dursun

Millî Eğitim Bakanlığı Eğitim Yöneticisi

sakin_dursun@hotmail.com

ORCID:0000-0001-6100-8122

\section{Özet}

Eğitim yöneticisi olan kişilerin stres yoğunluklu bulunması öğretmen, kurum, iş performansı, öğretmen çevresi, veli motivasyonuyla öğrencilerin başarma düzeylerini menfi yönde etkilemektedir. Stres yoğun durumun menfi tesirlerinin engellenmesi ve stres ile baş etme yöntem ve ilkelerinin bulunması, kuruluş faydasına yönlendirilmesi randıman bakımından gereklidir. Bu çalışmanın amacı da eğitim yöneticisi olan kişilerin ferdî ve kurumsal stres sebeplerini bularak bu durum ile baş etme taktik ve stratejilerini ne şekilde geliştireceklerine dönük semptomları tanıtmak şeklinde açıklanabilir.

Stres sebepleri, bu durumun sebeplerinin oluşumuna dair ikincil meselelerin ne olduğu, bunların çözülmesi yönünde eğitim yöneticisi olan kişilerin ne türlü uygulama yapabileceğinin araştırıldığı bu çalışmada yöneticilik ve eğitim yöneticiliği ifadeleri üzerinde durularak bazı tespitlerde bulunulmuştur. Bahsi geçen hususların ferdî ve kurumsal belirtileri ve neticeleri üzerinde yoğunlaşılarak eğitim yöneticisi olan kişilerin stres ile başa çıkma stratejileri irdelenmiştir.

Anahtar Sözcükler: Eğitim Yönetimi, Stres Sebepleri, Stres Neticeleri, Stres İle Başa Çıkma Taktikleri.

\section{Strategies of Education Managers for Coping with Stress}

\begin{abstract}
The fact that the people who are educational administrators are full of stress negatively af ect the teachers, school, job performance, teacher environment, parent motivation and the success levels of the students. Inhibiting the negative effects of stress and finding methods of coping with stress and directing it to the benefit of the organization are necessary in terms of efficiency. Therefore, the general purpose of the research is explained as to introduce the findings on how to find the personal and institutional causes of stress of the people who are educational administrators and how to develop their coping tactics.
\end{abstract}


In this study, in which the causes of stress, the secondary issues related to the formation of its causes, and how the people who are educational administrators can apply to solve them, determinations have been made by emphasizing the expressions of management and education management. By focusing on the personal and institutional symptoms and consequences of the aforementioned issues, the tactics of coping with stress of the education administrators were examined.

Key Words: Educational Management, Causes of Stress, Consequences of Stress, Tactics for Coping with Stress.

\section{Giriş}

Eğitimin ereğine ulaşması için, kurumda öğretmen, yönetici ve eğitim müfettişlerinin iş birliği ve ahenkle çalışması gerekmektedir. Kurumda çalışan kişiler içersinde ahenk gayet mühimdir. Stresse uyum zorlaştıran duruma vücudu meydana getiren organların gösterdiği reflekstir.

İnsan, hayatında çokça sıkıntı, güçlük ve zorluklarla karşılaşır. Bunlarsa durumlara nazaran iç ve dış etkilere endeksli olabilmekte. Kişiler bahsi geçen durumların üstesinden gelebilmek için değişik başaçıkma gayreti göstermekte. Bunlar günlük yaşamda ve de çalışma hayatında her an önümüze çıkabilmesi olası durumlarıdır. Kişilerin akordunu etkileyen, kuvvetini zayıflatan ve güçlükle değerlendirilebilen, iç ve diş çevre arasındaki etkileşim neticesinde meydana gelen bu durumları stres şeklinde tanımlanır.

Kurum ulusumuzun yüksek stres içerikli mekanlarının başında gelmektedir. Eğitim yöneticisi olan kişiler, söz konusu mekanın en mühim yapı taşlarından birisidir. Eğitim yöneticisi olan kişiler, millî eğitimle öğretmen, öğretmenle öğrenci ve de öğretmenle veliler içeresinde bağ kurma görevindedirler.

Çalışma mekanında meydana gelebilecek tüm aksaklık ve eksiklikler eğitim yöneticisine baş vurularak giderilmeye çalışılmaktadır. Bu neden ile eğitim yöneticisi olan kişilerin çokça ifadesini bulan sözcük olan stres ile karşılaşmaları kaçınılmaz hâle gelmektedir.

Eğitim yöneticisi olan kişileri çokça etki altına alan stresle alakalı kaynakları sıralanmasında, yönetim tarzının ekseriyetle ilk sırada bulunduğu görülmekte. Eğitim yönetici kişilerin stres düzeylerinde önemli bir motif şeklinde tespit edilen kurumu yönetme çabası yoğun ölçüde stres meydana getirici şeklinde algılanmakta.

Stres yoğun bir mekânda iş gören eğitim yöneticisi olan kişilerin verimsizliği; öğretmen, öğrenci, çalışma dostları, ailesi ve tüm topluluğa yansıyabilmektedir. 


\section{Yönetim ve Ĕgitim Yönetimi}

\section{Yönetim Kavramının Çerçevesi}

Yönetim uluslararası bir olgudur. Önce insanla uğraşır. İnsanoğlunun topluluk hayatında diğer kişiler ile olan ilişkisini, değişik etmenler altındaki davranım kalıplarını incelemektedir. (Güçlü, 2003: 63). Bu durumun kısaca sıra yüz yıldan uzun zamandır gelişmekte olan bir tanımdır.

Yönetimin mana fikrinin ana ögesini ve konusunu meydana getiren yönetim konsepti, en geniş manada; amacın tesirli ve randımanlı bir biçimde gerçekleşmesi için bir insan gurubunda iş birliği ve eş güdümleme sağlamaya dönük şeklinde sürdürülmekte olan işlerin bütününü dile getirmektedir. (Budak ve Budak, 2004: 10).

Yönetim, kurumsal amacın tesirli ve randımanlı şekilde gerçekleştirilmesi için, yönetim bağıntıları olan planlılık, örgütlülük, yürütme ve eş güdüm ve denetim faaliyetlerinin bütünüdür. Yönetim uluslararası bir vetire, sosyal hayat kadar köklü bir yetenek ve gelişmeye devam eden olan bilim dalıdır (Genç, 2008: 16).

Bundan da anlaşıldığı gibi, yönetim ereğe yönelen, insani ve sosyal bir vetiredir. Yönetimde vazifeler ifa eden, müşterek efor ve çalışma sahalarında bulunan fertleri, iş gören ve iş gördürülen, yöneten ve yönetilen, memur ve amir gibi münferit ifadelerle anılan sosyal bir farklılaşmaya uğrar. Hep yönetim süreci ve fonksiyonlarının söz konusu bulunduğu durumlarda, emirler alanla emirler verenlerin mütemadiyen mevcudiyeti söz konusudur (Ertürk, 2009: 6).

Çağımızda teşekküllerin genişlemesi, iş bölümünün fazlalaşması, her birisi değişik bir ihtisas sahası olan değişik faaliyetlerin meydana çıkması neticesinde yönetim anlayışı ciddi ölçüde ehemmiyet kazanmıştır.

Yönetim biliminin kurucusu olan Henry Fayol yönetim anlayışının özelliğini şöyle açıklamakta; Fayol, bir teşekkülü ereğine yönelik yöneltmek için, önce teşekkül dahilinde yer alan değişik faaliyetleri, hangi çalışmaların yapıldığını guruplar şeklinde belirlemiştir. Teşekküllerde bahsi edilen faaliyetleri istihsal faaliyetleri, malî faaliyetler, istikrar faaliyetleri, tecimsel faaliyetler, muhasip faaliyetler, yönetim faaliyetleri şeklinde altı guruba bölmüştür. Bu neden ile yönetim anlayışının diğerlerine benzemeyen tüm iş ve işlemlerden değişik yapısı olan bir faaliyet olduğunu netçe belirtmektedir (Budak ve Budak, 2004: 6). 
Yönetim anlayışının güçleşmesi, ehemmiyet kazanması, değişik bir işlev şekline gelmesi ve imâl ögeleri içerisinde yer alması yarım asırda gerçekleşti. İmal ögeleriyle alakalı bir sıralanma yapıldığında bunların beş gurupta toplanıldığı görülmektedir:

a. İnsani güç

b. Donanım

c. Ham madde ve ekipman

d. Nakdi sermaye

e. Yönetim anlayışı (Budak ve Budak, 2004: 13).

Çağdaş örgütlülük düşüncesine yaslanan bu sıralanma şekli umumiyetle tüm yönetim bilimcilerce benimsenen anlayıştır. Çağdaş düşünürlere göre yönetim etkinliği imâl ögesi şeklinde kabul görmektedir (Budak ve Budak, 2004: 13).

Yönetimin temel ereği bunların eş güdümü yolu ile kurumsal amacın tesirinin bir ölçüde düzene sokulmasını sağlamaktır. Bu neden ile yönetimin temel amacı, mutlak kurumsal faaliyetler meydana koymaktır.

Yönetim anlayışı söz konusu ereğine, birinci elden yönetim bağıntısı olan planlamayla ulaşır. Kurumda çalışan kişilerin temel görevi, planlama ile belirlenmiş olan amacın gerçekleşmesini sağlamaktır. Tüm yönetim faaliyetleri bir amaçsal görev için olduğundan kurumsal hedefe yönetim anlayışı ile ulaşılır (Genç, 2008: 18). Kurumun ve çalışan kişilerin başarması ereğe ulaşmada gösterilen faaliyetlerin düzeyi ile ölçülmektedir.

\section{Eğitim Yönetimi Kavramının Çerçevesi}

Eğitim yönetimi toplulukların eğitimle alakalı gereksinişlerini karşılamak için oluşturulan eğitim kurumunu daha önce belirlenmiş olan ereğini gerçekleştirmek için etkili teşekkül geliştirme ve yenileştirme vetiresidir. Eğitim yönetimi anlayışının ereği eğitimsel imkanları eğitimi gereksinen ve talep eden vatandaşın faydalanabileceği şekilde genele ulaştırmaktır. Bu durum Anayasa ve Millî Eğitim Kanununda yer almaktadır. Diğer taraftan millî eğitim sisteminin ereğine yönelik eğitimi geliştirmek suretiyle kalifiye öğrenci yetiştirmektir (Başaran, 1994: 12-13).

Eğitim yönetimi eğitimle alakalı kuruluşların ereğine ulaşabilmeleri için araç-gereçlerin, insanoğlunun, paraların en tesirli ve randımanlı bir biçimde kullanılmasını ve de yerleştirilmesini 
irdeleyen bilim dalıdır. Eğitim, yönetim biliminin dalıdır. Yöneticilik ile alakalı umumî kavramını yönetimden, hususî kavramını yönetimsel uygulamalardan almaktadır (İlgar, 1996: 10).

Eğitim yönetimi anlayışının görevi, eğitim yöneticisi olan kişilerin mesuliyet ve göreviyle açıklanabilir. Eğitim yöneticileri öğretmenler, hizmetliler, öğrenciler, veliler, çevresel önderler gibi değişik kültür ve eğitim seviyesinde yer alan, değiş̧ik beklentisi olan ögelerle ilişkisellik oluşturmak suretiyle bunların beklenti ve isteklerini bağdaştırmak ve hakça yönetim anlayışı devam ettirmekle mükelleftir. Bu durumun için tesirli yönetim şekli benimsemek mecburiyetinde olan eğitim yönetici kişilerin, insani ilişkiler, halk ile ilişkiler ve güdülemelerde yeter düzeyde olmalar gerekir (Yavuz, 1997: 510).

Eğitim yönetimi kavramı eğitim anlayışının bütünüyle ilgilidir. Eğitim yönetimi, sistemi tümden birleştirme ve çözümlemeyi amaçlar (Koçel, 2001: 61). Eğitim yönetimi kurumu kaplayan tepe aygıt pozisyonunda yer alır. Kurum kurumu eğitim yönetimi dahilindeki temel aygitlardan en kritik ve en tesirli olanını ifade eder (Açıkalın, 1998: 2).

Başaran'a göre eğitim yönetimi anlayışının daha tesirli çalışabilmesi şu koşullara bağlıdır:

a. Bireyin hayatında eğitim anlayışının mütemadiyen oluşum olduğu ikrar edilerek, bu oluşum dahilinde eğitim yönetimi anlayışının sistemli ve kapsamlı Eğitimle alakalı kurumların yaygın ile örgün eğitim anlayışının, vatanın insani gücüne ve imâl kapasitesine desteği tesirli şeklinde planlanmal1.

b. Görev, tesir ve mesuliyet, bakanlığın ilde, ilçede ve kurum yönetiminde paylaşılmalı; mevcut merkezî yönetim anlayışından yerel yönetim anlayışına dönük kurumların tesirliliğini arttracak seviye ve yeterlikte kullanılmalı.

c. Kurum, eğitimle alakalı hizmet ve faaliyetlerin üretildiği başlıca aygıt özelliğine ulaşmalı.

d. Eğitimle alakalı kurumlarında planlama, değerlendirme, ölçme, plan geliştirme, denetim, toplumun eğitimi, özel eğitim, beslenim, kurum kitaplı̆̆ gibi ihtisas hizmet ve imkanları ilçedeki eğitim müdürlüğüne dek inmeli.

e. Kurumlara yardımcı olacak eğitim uzmanları atanmalı, kurumun seviyesi en düşük yüksek lisans seviyesinde olmal1.

f. Eğitim sisteminde her kademedeki kurumun ve kuruluşun yönetim şekli, eğitim iş görenlerinin ve eğicilerin yönetime katılmasını sağlayacak özelliğe kavuşturularak, demokratikleştirilmeli. 
g. Okulöncesi eğitim, temel eğitim, ortaöğretim kurumları ve yaygın Eğitimle alakalı kurumları, şahsî özeliklerine nazaran tesirli şekilde, ancak biri birisi ile tümleşik şekilde örgütlüce yönetilmeli.

h. Yüksek öğretim, şahsına mahsus örgütlenip yönetilir iken, eğitim sisteminin örgün ve yaygın eğitim kanadı ile dirik bir tesirleşim ve yardımlaşma dahilinde olmalı.

i. Eğitimin uygulama ile ilişkisini güçlendirme, maliyet oranını düşürme ve çalışma hayatına uyarlayabilme için, her eğitim kuruluşu, şahsî seviyesinde, iş yerleriyle enerjik ilişkiler kurmalı.

j. Eğitim anlayışı dil, ırk, din, cins, aileler ve mezhep ayrımına, zümresel egemenliğe izin veremeyecek ölçüde işletilmeli.

k. Seçkin ile ayrıcalıklı olanları eğitecek kurumlar açılmamalı.

1. Eğitilenlerin çağdaş yabancı dilleri öğrenimleri için elzem olan imkanlar hazırlanılmalı ancak yabancı dille öğretim yapılmamalı.

m. Eğitimin devlet aygıtının başlıca görevi olmalı. Halk ve vatandaşlar, eğitime destek bulunması amacı ile teşvik edilmelidir. Özel ve tüzel kişilerce kurum ve dersliklerin açılması sağlanmalı.

n. Eğitim anlayışında özgürlüğün sağlanılması için, temelden eğitimden geçmeyen vatandaşın bundan faydalanması sağlanmalıdır, orta ve yüksek öğretim imkanları süratle yaygınlaşmalıdır (Başaran, 1994: 140 - 141).

Yakın zamanlarda ilçe millî eğitim müdürlüklerinin kurulması, ilk öğretimin 8 sene mecburî bulunması, eğitimde dört+dört+dört özelindeki ilk okul, orta okul ve orta öğretim şeklindeki formal değişiklikler eğitim aygıtımızın yapısal boyutunun, tesir ve mesuliyet ögelerinin tekrar gözden geçirilmesini zorunlu kılmıştır (Başar, 1992: 115).

\section{Eğitim Yöneticilerinin Stresle Başa Çıkma Yöntemleri}

\section{Stres ile Başa Çıkma Yöntemleri}

Braham'ın (2004: 39) modeline nazaran başaçıkma yolları iki başlık altında toplanabilir. Bunlar; problem merkezli başaçıkma ve duygu merkezli başaçıkmadır. 


\section{Problem Merkezli Başa Çıkma}

Sorun merkezli başetme çabaları, stres yoğun bir durumu değiştirmek, tesirini önlemek veyahut hafifletmek için harekete geçilmeyi içermektedir. Problem merkezli başa çıkmanın hedefi stres yoğun durumun taleplerini hafifletmek ve de kişinin bu durum ile uğraşacak kaynaklarını geliştirmektir. Bir kimse bir problemle başa çıkmak için bilgi arayışına girebilir (Öztop, 2000: 47). Sorun merkezli başa çıkma problem meydana çıkmadan da pekala başlayabilir. Bu yaklaşım proaktif başa çıkma şeklinde isimlendirilir. Bu durumda birey stres yoğun durumun potansiyel sebeplerini sezerek duruma koşut palanlar yapar. Pro-aktif başa çıkmayı kullanmak bir kimsenin hiçbir vakit stres yaşayacağı manasına gelmez ancak kişinin bu durumun üstesinden gelebilmesini sağlar. İnsanlar karşı karşıya geldikleri stres yoğun durum önünde yapabilecekleri olduğuna inandığında problem merkezli başa çıkmayı kullanmak eğiliminde olur (Braham, 2004: 40).

\section{Duygu Merkezli Başa Çıkma}

Duygu Merkezli Başa çıkma, stres yoğun durumun hissi neticelerini azaltmayı ve de düzenlemeyi içermektedir. Birey şahsî duygularını düzenlemeye çalışır. Mesela bir hissi ilişkisellik sona erdiğinde insanlar yaşadıkları menfi stres duyguları ile baş etmek için günlük aktivitelerle dikkatlerini dağıtmaya çalışırlar. Stres yoğun duruma reaksiyon şeklinde ortaya çıkan duygu merkezli başa çıkma; mevcut durumun zihinsel şeklinde tekrar değerlendirilmesini, başkalarından yatıştırma ve destek beklemeyi, yapılabilecek hiçbir şey yoksa meseleyi kabule çalışmayı ve duyguyu boşaltmayı içermektedir (Ünsar ve Alkın, 2007: 90).

Duygu Merkezli başa çıkmada birey aşağıdaki savunma mekanizmalarını kullanmaya yönelir: Kaçma kaçınma, inkar, problemlerden uzaklaşma, hazcı kaçınma, sosyal destek, yüzleşici başa çıkma, kuruntuluca düşünce, zihni manada meşgul olmama. Bunlardan inkâr, durumun gerçekliğini reddetme, görmeden gelmeye çalışma çabasıdır. Kaçma kaçınma, içki, sigara tüketip iyi hissetme çabasını içermektedir. Uzaklaşmaysa stresi oluşturan uyarıcılar hususunda düşünmeyi reddetme eylemini içermektedir (Ünsar ve Alkın, 2007: 90). 


\section{Stres ile Başa Çıkma Taktikleri}

Stres ile baş etmede kullanılacak taktikler ferdî ve kurumsal taktikler şeklinde sınıflandırılabilir. Özgüven'e (2004: 62) göre stres ile başa çıkma yöntemleri şeklinde ferdî yöntemler arasında; gevşemek, destek, vakit yönetimi, egzersizler gibi yöntemler uygulanabilir iken; kurumsal yöntemlerin arasında; görevsel tanımlar, iş gören seçimleri ve iş gören terfileri, ücretlendirmeler, iş gören eğitimleri, başarma değerlendirmesi, meslek planlaması uygulanabilir (Özgüven, 2004: 62-63).

\section{Stres ile Başa Çıkmada Bireysel Taktikler}

Stres ile başa çıkmada ferdî yöntemler, kurumsal düzeyde başa çıkma taktikleriyle birlikte uygulandığında tesirini çokça hissettirmektedir (Güçlü, 2001: 137).

Stres ile başa çıkmada sıralanan ferdî taktikleri şu şekilde sıralamak söz konusudur:

Benlik Özelikleri Değiştirilmesi: Zihinsel ve tutumsal vetireleri kullanmak suretiyle benlik özeliklerinin değiştirilmesi, bireylerin stres yoğun durumları hakkında değişik düşünme ve davranmasını sağlamaktadır (Aydın, 2002: 39).

A Tipinde Davranım Şeklinin Değiştirilmesi: Telaş ve aceleden vaz geçmeler, vakit baskısından kurtulmalar, sâkin iş ortamı hazırlamalar, şahsına vakit ayırmalar v.s.

Fizikî Hareketler (Sportif ve Egzersizler): Stres tepkisi damarda darala sebep olduğundan, hücre verilerine akan kanın meblağında tenakusa sebep olmaktadır. Fizikî aktivite (yürümek, koşmak, bisiklet binmek v.s.) her yaş ve baştan kişilerce stres ile mücadelede mühim rol oynamaktadır (Baltaş ve Baltaş 2000: 209).

Solunumsal Egzersizler: Nefes almak başlı başına gevşemek olduğundan, tüm rahatlama egzersizinin mühim parçasıdır. Nefes bireyde başlayacak veyahut başlayan stres refleksi sistemini azaltmada ve tersine çevirmekte önemlidir (Baltaş ve Baltaş, 2000:164).

Derin Düşünme: Derin düşünme, bedeni fizikî ve hissi şeklinde dinlendirme için dahili yoğunlaşma ve sâkinliği barındıran faaliyettir. Derin düşünme bireylerin stres yoğun durumlardan uzaklaşmasına ve stresin belirti hâllerinden bireyin daha düşük tesirlenmesine yardımcı olmaktadır (Aydin, 2002: 340). 
Sosyal Destekler: Bireyin başka bireylere veyahut guruplarla var olan iletişimini anlatır. Bireylerin aile, topluluk ve çalışma hayatlarında birlikte olduğu diğer insanlarca desteklenme düzeyleri, paylaşım oranları ve birliktelikten aldıkları zevk, onların stres ile mücadele etmedeki başarma düzeylerini arttırmakta ve stresten daha düşük ziyan görmelerini sağlamaktadır (Aydın, 2002: 4041).

Gevşeme: Gevşeme eğitimi, stresin altında bulunan bireylerde başlayan stresin tepkisinin zıddı bir tesir yapar. Gevşseme tekniği uygulandığında vücutta başlayan psiko-somatik stresin tepkileri azalır ve zararı ketlenmiş olur (Aydın, 2002: 41).

Biyolojik Dönüt: Bireyin olağan ve olağandışı ve kendi farkında olmadığı bedensel tepkilerinin, araç yardımıyla farkında olduğu eğitim planı dahilinde otonom faaliyetlerini (bedensel sıcaklığı, ter bezi salgıları v.s.) istediği yönde düzenlemeyi kavradığ bir yöntemdir (Baltaş ve Baltaş 2000 : 170)

İbadet ve Dua: İbadet ve dua, tansiyon ile baş etme için yüz yıllardır kullanılmakta. Dua etme bireyin umut ve iyimserlik yönünü de yükseltir (Aydın, 2002: 42).

Vakit Yönetimi: Vakti düzenli kullanmama işlerin en sona bırakılması vakit baskısının içinde olma durumu mühim bir stres duygu kaynağıdır. Bundan dolayı yapılacak işlere ilişkin şeklinde planlama yapma ve vakti iyi kullanmak, vakti tesirli kullanmak, vakit baskısından kaynaklanmış olan stres ile baş etmede epeyce tesirli bir yöntemdir (Pehlivan, 2000: 83).

\section{Stres ile Başa Çıkmada Kurumsal Taktikler}

Kurumsal stres ile baş edilebilmesi ve kurumsal stres yoğun durumun azaltılması için kullanılabilecek bütünsel taktikler içerisinde aşağıdakileri sıralamak söz konusudur:

Kurumsal Atmosfer Yaratma: İş görenlerin karşılaştıkları iş streslerinden olan örgütsel yapılar ile bürokratik yapılanmalardır (Pehlivan, 2000: 154).

İş Zenginleştirme: İşsi zenginleştirmek işlerin barındırdığı mesuliyet, tanınmak, başarma imkanı türü faktörlerin değişik beceri, görev tanımı, anlamlılık, özerklikler gibi işlerin muhtevasına dönük özeliklerin geliştirilmesini içermektedir. Zenginleştirilen vazifeler, sıradan ve yapılandırılan işlere nazaran stresle alakalı durumların azaltılmasını sağlamaktadır (Pehlivan, 2000: 154).

Kurumsal Rolleri Belirleme ve Çatışmaların Azaltılması: Rol çatışması ve belirsizlikler, ferdî stresle alakalı kaynaklarının başında gelmektedir. İyi bir kurum, kâfi hizmet içi eğitimi ve bizatihi 
iş üzerinde verilecek bilgi ve eğitim, kişilerin ne yapacaklarını gösteren görev tarifleri ve çalışan kişilerden zamansız bilgi istemeyi ketlemeye dönük düzenlemeler rol belirsizliğini ve kişiler arası çatışmayı mühim ölçüde azaltabilir. Rolleri belirlenmiş bir kurumda çatışmalar önlenmiş olacağından bundan kaynağını bulan iş stres yoğun durumu azalacak ve de meydandan kalkacaktır (Pehlivan, 2000: 155).

Meslekî Gelişim Yollarının Danışmanlığı: Kurumlarda genellik ile iş görenlerin meslekî planlamasıyla alakalı geçiş ve yükselmelerin ananevî yollarla yapıldığı görülmekte. Bireylerin yükselmeleri ve ilerlemesi, genellik ile yöneticilerce yapılmakta. İş görenlerin örgüt dahili ilerlemenin mümkün olduğu durumlarda örgütsel yapılarda ileri basamağa yükselmek isteyecektir. $\mathrm{Bu}$ durum da yaşanma olasıllığı fazla stres yoğun durumu önleyecektir (Pehlivan, 2000: 155-156). Işs Yerinde Mutlu Ortamlar Oluşturma: Büyük kurumların geneli, iş yerinde mutlu ortamlar oluşturmanın ehemmiyetini kavradıklarından, buralarda iş görenlerce neşeli havanın kullanılması teşvik edilmekte. Etkileyici yöneticiler, randımanlığı sadece kısacık dönem için istemez; iş doyumu fazla olan iş görenlerin kurumun uzunca dönemdeki faydaları için hayatî öneme haiz olduğunu bilirler. Başarılı yöneticiler, en koşut iş stres yoğun durumunun verim için ihtiyaç olduğunu da bilirler (Pehlivan, 2000: 156).

Kurumlarda yönetici olan kişilere önemli mesuliyet düşmekte. Stres ile başa çıkmada, eğitim yöneticisi olan kişilerin stres ile başa çıkmalarını sağlayacak ve olağan dışı stres yükü altında kalmasını önleyecek bir takım vazifelerin düştüğünü belirtmek gerekir. Bunları aşağıdaki şekilde siralamak mümkündür (Aydın, 2002: 323-324):

a. Kurumda iş görmek için kafi ölçüde cazip ortamlar oluşturmak.

b. Rollerin çatışması ve belirsizliğini en aza indirgemek için olabildiği ölçüde net ve düzenli rollerin beklentisini sağlamak.

c. Kurumda değişme ve devamll1ık içerisinde koşut dengeler oluşturmak.

d. Mümkünse iş görenlere kısa dönemli verimlik kadar, uzun dönemli sıhhatli iş doyumu, kendisini ifade etme imkanı sağlamak suretiyle, iş yerindeki ilerleme ve gelişimin gerçekleşmesi için en ileri düzeyde esnek yapı göstermek.

e. Lüzumsuz strese sebep olabilecek örgüt dahilindeki stres düzeyine ve iş koşullarına karşı dikkatlice davranmak.

f. Stres dahilindeki iş görenler için stres yönetim hizmetlerini desteklemek. 
Stres yoğun durumun menfi neticelerini hafifletmek amacı ile oluşturulan davranımlar hissi tepkiler ve yöntemler, stres yönetimi tekniği şeklinde isimlendirilmektedir. Stres yönetimleri bireyin haiz olduğu beden ve ruh dengesini sağlama ve kalite yapısını arttırmak bakımından mühimdir. Bireyin çalışma hayatındaki verimliğini en üst ölçüye çıkartmak için de gereklidir. Çalışanların iş hayatından kaynak bulan stres yoğun durumu hafifletmek veyahut izale etmek amacı ile kurum ölçüsündeki stres kaynağını en aza indirmeyi veyahut kontrol etmeyi amaçlayan kurumsal stres yönetimine dair mücadele taktikleri diğer taraftan kısaca açıklanmıştır (Bakan, 2004: 49).

\section{Kurumsal Stres Yoğun Durumun Azaltılması İçin Eğitim Yöneticilerine Düşen Görev ve Sorumluluklar}

Kurumun ara ve ileri düzey yönetici kişilerin uygulayacağı ve kurumsal stres yoğun durumun çalışanlar üzerindeki tesirlerini azaltacakları bir takım yönetsel süreç ve yöntemler dahilinde bulunması, kurumda ve evde gerek kurumsal verimlik bakımından gerekse de uzunca dönemli iş gücü kayıplarını önlemek bakımından mühimdir. Eğitim yöneticisi olan kişilerin kurum üzerindeki stres yoğun durumu hafifletmek için yapabileceği bir takım öneri ve tespitler şu şekilde siralanabilir (Pehlivan, 1991: 641-642):

a. Kurumu cazip bir merkez yaparak çalışan kişilerin yaptığı işlerden yüksek doyum almasını sağlayabilmek.

b. Öğretmen ve öğrenciden beklentisini net bir biçimde anlayabilecekleri yöntemler ile anlatabilmek.

c. Kurumsal değişim ve gelişimlerin kontrolünü elde tutabilecek ara elemen istihdamını sağlayabilmek.

d. Öğretmen ve öğrencilerin fikirlerini ve problemlerini dinleyebileceği ilişkiler oluşturabilmek, süreli çalışmalar yapabilmek.

e. Öğretmen ve öğrenciler içerisinde sosyalleşmeyi sağlayacak faaliyetler yapma ve birliktelik duygusunu güçlendirecek ortam oluşturabilmek.

\section{Sonuç}


Eğitimle alakalı kurumların evvelden belirlemiş olduğu ereğe ulaşabilmesi, kısaca tesirli olabilmesinde en mühim ölçütlerden birisi biricik idareci şeklinde kurumun müdürüdür. Kurum idarecisi olan kişinin vazifesi, kurum kaynaklarını randımanlı şekilde kullanmak suretiyle, kurumun ereğine koşut şeklinde değerlendirebilmektir. Kurumdaki mevcut stresle alakalı kaynaklarını meydandan kaldırmada ve de azaltmada kurum müdürüne çok mühim görev ve sorumluluklar düşmekte.

İyi eğitim yöneticisi personellerini tanımaya çalışan, problemleri ile ilgilenen kişilerdir. Bundan ötürü özelikle yeni görevine atanan eğitim yöneticisi olan kişilere plan hazırlanılmasından kurum dahili ve harici problemlerin çözümüne dek meslekî yönden rehberliğin yanı sıra ihtiyaç duyacağı motivasyon destekleri verilmelidir. Yöneticiler yetkesini kurumsal stresle alakalı kaynakları meydandan kaldırma ve hafifletme için kullanmalıdır.

Eğitim yöneticisi olan kişilerce talep görülmediği sürece kurum program ve palanları her sene değiştirilmemeli. Sınıf kalabalığı sıkıntısı çözümlenmelidir. Bu durum da eğitime çok fazla malî destek ayırılması sebebi ile yeni kurum ve kuruluşların ve personel görevlendirmelerinin yapılmasıyla giderilebilir.

Kurumların fizikî koşulları geliştirilmeli ve düzeltilmelidir. Eğitim yöneticisi olan kişilere destek duyacakları eğitim materyalleri ve kaynakları sağlanmalı. Eğitim yöneticisi olan kişilerin meslekî yayımlara kolayca ulaşabilmesi sağlanmalı.

Eğitim yöneticisi olan kişilerin çağımız şartlarında tesirli olabilmesi için bilgi ve beceriye haiz bulunması gerekmektedir. Ĕ̆itim yöneticileri mesleğin dahilinde kendisini yetiştirmelidir. Bu durumun sebebi, eğitim yöneticisi olan kişilerin yetiştirildikleri eğitim kurumunda kafi meslekî eğitimi almamış olmasıdır. Yetenek, beceri, bilgi ve meslekî eğitim, mevcut koşulların geliştirilmesinde çok mühim bir etkiye haizdir.

Eğitim yöneticisi olan kişilerin bir çoğu değişik nedenden ötürü üstlerinden destek istemek hususunda çekimser davranmaktadır, birbirleri ile rekabet dahilinde ve benzeş mekanda olduğu hâlde birbirlerine destek olmamakta. Bu durumu meydandan izale etmek için eğitim yöneticisi olan kişiler içerisinde gelişkin iletim modülü kurulmalıdır ve ilişkisellik planlı bir biçimde düzenlenmelidir. Meslekî konular ile kurumlarda karşılaştıkları problemler hakkında konuşabilmelidir; dostça ve dostça olabilmelidir, birbirlerine destek verebilmelidir. 
Tecrübeli eğitim yöneticisi olan kişiler yeni görevine başlayan kişilere rehberlik edebilecek kişiler olmalı. Yeni görevine başlayan eğitim yöneticisi olan kişilere düşünce ve tecrübelerini anlatabilmeli ve destek olabilmeli. Diğer taraftan onlara motivasyon desteğinde bulunmalıdır. Eğitim yöneticisi olan kişilerin meslekî yönden kendisini geliştirebileceği koşut meslekî imkanların sağlanılması, çokça eğitim faaliyetleri, seminer, meslekî toplantılar ve konferanslar düzenlenmesi gerekmektedir. Eğitim yöneticisi olan kişiler de kendisini geliştirebilmek için değişik yollara baş vurmalı ve kendisini yenileme ve geliştirmeye istekli olmalı. Eğitim yöneticisi olan kişilerin malî durumlarının yeterli ölçüye getirilmesi gerekmekte. Maaşı hayat standardına görece ayarlanmalı.

Bir topluluğun kalkınma ve gelişimi için öncelikle eğitimli insan gücüne ihtiyaç bulunmaktadır. Eğitimli insanlar ise okullarda yetişir. Kurumların girdi ve çıktısıysa insanın kendisidir. Buysa onu diğer kurumlardan ayırır. Bir kurumda öğrencinin nitelikli yetişmesi ne türlü öğretmenlerce verilen eğitim kalitesine bağlı ise öğretmenin nitelikli yetişmesi de eğitim yöneticisi olan kişilerin nitelikli olmasına bağlıdır. Bu durum için eğitim yöneticisi olan kişilerin işlerinden elde ettikleri doyum oranının en ileri seviyede bulunması gerekmektedir. Böylelikle bu kişiler daha randımanlı olabilecektir.

\section{Kaynakça}

Açıkgözü, K. (1994). Eğitimde Etkili Yönetici Davranışları. İzmir: Kanyılmaz Matbaası.

Akat, T. ve Budak, G. (1994). Teşekkül Yönetimi. İstanbul: Beta Basım Yayım Dağıtım. A.Ş. Aydın, M. (1993). Çağdaş Eğitim Denetimi. Ankara: A Yayınları.

Balcı, A. (2000). Öğretim Elemanlarının İş Stres Durumu, Kuram ve Uygulamalar. Ankara: Nobel Dağıtım.

Balc1, A. (2001). Etkili Kurum ve Kurum Geliştirme. 2. Bask1, Ankara: Pegem A Yayıncılık. Başar, H. (1992). İlkokulda Yönetici-Öğretmen İletişimi. M.Ü. Eğitim Fakültesi Dergisi, Sayı: 8, s. 115-117.

Başaran, İ. E. (1992). Yönetimde İnsan İlişkileri Yönetsel Davranım. Ankara: Kadığlu Matbaası. Başaran, İ. E. (1982). Eğitime Giriş. Ankara: Kadıŏglu Matbaası.

Binbaşıŏlu, C. (1998). Eğitim Yöneticiliği. Ankara: Binbaşıŏlu Yayınevi.

Budak, G. ve Budak, G. (2004). Kurum Yönetimi. İzmir: Hayat Yayıncılık. 
Can, H. (2005). Kurum ve Yönetim. Ankara: Siyasal Kitabevi.

Çelik, V. ( 2003). Eğitimsel Önderlik. 3. Baskı. Ankara: Pegem A Yayıcılık.

Dinçer, Ö. ve Fidan, Y. (1996). Kurum Yönetimi. İstanbul: Beta Basım.

Erdoğan, İ. (2000). Kurum Yönetimi ve Öğretim Önderliği. İstanbul: Sistem Yayıcıllk.

Eren, E. (2000). Kurumsal Davranım ve Yönetim Psikolojisi. 6. Baskı, İstanbul: Beta Basım Dağıtım.

Eren, E. (2009). Yönetim ve Kurum (Çağdaş ve Küresel Yaklaşımlar). 9. Baskı. İstanbul: Beta Yayınları.

Ertürk, M. (2009). Kurumlarda Yönetim ve Kurum. Genişletilmiş ve Gözden Geçirilmiş 4. Baskı. İstanbul: Beta Yayınları.

Genç, N. (2007). Yönetim ve Kurum Çağdaş Sistemler ve Yaklaşımlar. Genişletilmiş 3. Baskı. İstanbul: Seçkin.

Güçlü, N. (2001). Stres Yönetimi. G.Ü. Gazi Eğitim Fakültesi Dergisi, S: 21, s. 91-109.

Güney, S. (2000). Davranış Bilimleri. Ankara: Nobel Dağıtım.

Işıkhan, V. (2004). Çalışma Hayatında Stres ve Başa Çıkma Yolları. Ankara: Sandal Yayınları.

Koçel, T. (2001). Yönetimde Stres Meydana Getiren Etkiler, Stres Yönetimi Semineri. Gebze: TUSSIDE Yayınları.

Ok, İ. (2006). İş Stres Durumunun İlköğretim Kurumlarında Kurum Yöneticileri Üzerindeki Etkisi. Konya Örneği. Konya: Yüksek Lisans Tezi, Selçuk Üniversitesi Sosyal Bilimler Enstitüsü. Öztop, F. (2000). Stres İle Başa Çıkma Yolları ve Bir Uygulama. Ankara: Yüksek Lisans Tezi G.Y.T.E. Sosyal Bilimler Enstitüsü.

Pehlivan, İ. (1995). Yönetimde Stresle İlgili Kaynaklar. Ankara. Pegem Yayınc1lık.

Şahin, N. H. (1998). Stres İle Başa Çıkma: Müspet Bir Yaklaşım. Ankara: Türk Psikologlar Derneği Yayınları.

Şişman, M. (1997). Geleceğin Önderlerinin Yetiştirilmesi ve Eğitimde Önderlik. İstanbul: 21. Yüzyılda Önderlik Sempozyumu (5-6 Haziran 1997) Bildirileri, Cilt: 1-2, s. 162-168, Deniz Harp Kurumu.

Şişman, M. (1996). Etkili Kurum Yöneticisinin Önderlik Davranımları. Bursa: DX Ulusal Eğitim Bilimleri Kongresi. 5-7 Eylül, Uludağ Üniversitesi.

Şişman, M .(2004) Öğretim Önderliği, Ankara: Pegem A Yayıncılık. 
Ülgen, H. ve Mirze, S. K. (2007). Kurumlarda Taktik Yönetim. 4. Baskı, İstanbul: Arıkan Yayıncilik.

Ünsar S.ve Alkın C. (2007). Önderlik Özelikleri ve Davranışlarının Belirlenilmesine Çalışması. Ankara: Gazi Üniversitesi İktisadi ve İdari Bilimler Fakültesi Dergisi. Sayı: 9/3, s. 75-94.

Yavuz, Y. (2001). Lise Yönetici Kişilerin ve Öğretmenlerin Kurumda Yerinden Yönetim ve Merkezden Yönetim Yaklaşımlarına İlişkin Görüşlerinin Karar Verme Sürecine Etkileri. İzmir: Doktora Tezi, Dokuz Eylül Üniversitesi Eğitim Bilimleri Enstitüsü.

Yavuz, Y. (1997). Nasıl Bir Eğitim Sistemi, Güncel Uygulamalar ve Geleceğe İlişkin Öneriler. İzmir: Bilsa Bilgisayar. 